\title{
Co-sensitization aided efficiency enhancement in betanin-chlorophyll solar cell
}

\author{
S. Sreeja ${ }^{1,2} \cdot$ Bala Pesala ${ }^{1,2}$
}

Received: 12 February 2018 / Accepted: 1 September 2018 / Published online: 11 September 2018

(c) The Author(s) 2018

\begin{abstract}
Dye-sensitized solar cells (DSSCs) are a promising third-generation photovoltaic cell technology whose advantages are low-cost fabrication, reduced energy payback time, better performance under diffuse light conditions and flexibility. Typically DSSCs employ toxic dyes such as metal-based porphyrins requiring complex synthesis. In contrast, natural pigments are environmentally and economically superior to synthetic dyes. However, narrow absorption spectra of natural pigments result in low efficiencies of the solar cells. Hence, co-sensitizing pigments with complementary absorption spectra, which increases the absorption band, is an attractive pathway to enhance the efficiency. In this paper, we report the performance of betanin-chlorophyll co-sensitized solar cell using betanin $\left(\lambda_{\max }=535 \mathrm{~nm}\right)$ and chlorophyll- $a\left(\lambda_{\max }=435 \mathrm{~nm}, 668 \mathrm{~nm}\right)$, natural pigments having complementary absorption spectra. Density functional theory simulations were performed to verify that the lowest unoccupied molecular orbital and the highest occupied molecular orbital levels of the dye molecules, are aligned appropriately with that of $\mathrm{TiO}_{2}$ and the redox electrolyte, respectively, which is necessary for optimal device performance. Electrochemical impedance spectroscopic studies were performed to determine parameters corresponding to the charge transfer processes in the dye solar cells. Individual and co-sensitized solar cells were fabricated and the co-sensitized solar cell demonstrated a higher efficiency of $0.601 \%$ compared to efficiencies of $0.562 \%$ and $0.047 \%$ shown by betanin and chlorophyll solar cells, respectively.
\end{abstract}

Keywords Dye sensitized solar cells (DSSCs) $\cdot$ Natural pigment sensitizers $\cdot$ Chlorophyll $\cdot$ Betanin $\cdot$ Density functional theory (DFT) $\cdot$ Electrochemical impedance spectroscopy (EIS) $\cdot$ Current-voltage $(I-V)$ characteristics

\section{Introduction}

Rapidly depleting fossil fuels and increasing greenhouse gas emissions leading to rising global temperatures and detrimental effects on our environment call for an imminent need for clean and renewable energy resources. Solar cells which effectively harness solar energy and convert it into electricity are the most promising renewable energy technology. The first generation of solar cells use silicon materials to capture solar energy but are rigid and bulky [1]. Organic solar cells (OSCs) and dye-sensitized solar cells (DSSCs)

Bala Pesala

balapesala@gmail.com

$1 \quad$ CSIR-Central Electronics Engineering Research Institute (CEERI), CSIR Madras Complex, Taramani, Chennai 600113, India

2 Academy of Scientific and Innovative Research (AcSIR), Taramani, Chennai 600113, India are the third generation of solar cells, developed after the silicon-based first generation and thin-film-based second generation solar cells. They have been a subject of extensive exploration over the last several decades, owing to their several advantages such as flexibility and low cost. OSCs typically use organic layers of electron donor and electron acceptor materials to form heterojunctions [2]. Simultaneously, there was also widespread research in photo-electrochemical cells-devices that convert light to electric power using semiconductor-electrolyte interfaces [3]. Typically high bandgap semiconductors (absorbing in the UV region) such as $\mathrm{TiO}_{2}$ were used in these photo-electrochemical cells to obtain high photo-voltages [3].

To extend the absorption spectrum into the visible spectrum, the idea of sensitizing the semiconductor with a dye came into the picture, giving rise to the DSSCs. In 1991, O'Regan and Grätzel realized the first dye-sensitized nanocrystalline $\mathrm{TiO}_{2}$ solar cells with an efficiency of $7.1 \%$ [4]. At present, efficiencies of $20 \%$ have been achieved by 
DSSCs [5]. In terms of ease of fabrication, the dye-sensitized solar cells are a promising alternative technology to the first and second generation solar cells and third generation organic solar cells. A DSSC is simple in construction and consists of a high bandgap semiconductor such as titanium dioxide $\left(\mathrm{TiO}_{2}\right)$ coated on an optically transparent conducting substrate-fluorine-doped tin oxide (FTO) glass electrode, sensitized by a dye and sandwiched by a platinum coated counter FTO glass electrode with an electrolyte redox couple in between. The high bandgap semiconductor $\left(\mathrm{TiO}_{2}\right)$ plays a dual role in DSSCs by acting as a scaffold for adsorption of the dye molecules, and as an electron acceptor and charge carrier $[3,6]$. Titanium dioxide $\left(\mathrm{TiO}_{2}\right)$ in its anatase form is the most widely used semiconductor material in DSSCs owing to its properties [3]. The electrolyte plays a key role in the regeneration of the excited dye molecules and electron transfer from the counter electrode. Iodide/triiodide redox couple $\left(\mathrm{I}^{-} / \mathrm{I}_{3}{ }^{-}\right)$has been the most widely used electrolyte due to its favorable kinetic rates. The reduction rate of the oxidized dye by the iodide ion is faster than the rate of recombination rate of the photoelectrons with the oxidized dye molecule by two orders of magnitude [3, 7], and hence the photogenerated carriers can effectively contribute to the photocurrent. DSSCs are potentially low cost due to their ease of fabrication and screen printing technologies that are available for mass production.

The sensitizer is the vital component of the cell, playing the major role of absorbing light and generating excitons. Pioneering studies of pigments for the Grätzel cells explored porphyrin derivatives synthesized from chlorophyll molecules [8] arriving at the cis-dithiocyanatobis $\left(4,4^{\prime}\right.$ dicarboxylic acid-2,2'-bipyridine) ruthenium(II) dyes, the most widely used dye in this field [9]. However, dyes based on ruthenium complexes are expensive because ruthenium metal is scarce and their preparation involves elaborate procedures. This has been the motivation to explore organic metal-free dyes, such as cyanines and hemi-cyanines, used earlier in OSCs, for use in DSSCs [10, 11]. Simultaneously, extensive research has also been ongoing in synthesizing analogues and derivatives of natural pigments [12, 13]. However, synthetic dyes require complex chemical preparation routes that result only in small yields. Compared to synthetic dyes, natural dyes abundantly available in plants can be easily extracted by facile methods. Moreover, they are non-toxic, environmentally friendly and biodegradable; and hence are being explored as alternative photosensitizers for DSSCs $[14,15]$. These pigments have naturally evolved over thousands of years to efficiently harness solar energy. Natural pigments such as betalains [14-17], chlorophylls $[18,19]$, anthocyanins [20, 21] and carotene [22] have been investigated as photo-sensitizers for solar cell applications. However, the main drawbacks of this type of solar cells are their low efficiencies and short lifespan. So far, maximum efficiencies of $1.5-2 \%$, and average efficiencies of $\sim 0.4 \%$ have been achieved by solar cells using natural photo-sensitizers [14-22]. Achieving higher efficiencies and improving stability would make natural pigment-sensitized solar cells an attractive alternative technology for portable or disposable electronic applications. One of the reasons for the low efficiency of natural dyes is low absorption coefficient and narrow absorption bands compared to typically used ruthenium-based dyes and cyanine or hemi-cyanine dyes [23]. Each pigment absorbs in a specific region of the incident solar spectrum. Combining multiple material systems [24, 25 ] has long been explored since the development of multijunction solar cells as a strategy to widen the absorption spectrum and augment the efficiencies of solar cells. Hence, co-sensitizing pigments with complementary absorption spectra, which increases the absorption band, is an attractive pathway to enhance the efficiency.

In this study, we investigate using a combination of two natural plant pigments: betanin, having absorption maxima at $535 \mathrm{~nm}$ [15], the green portion of the spectrum and chlorophyll- $a$, having absorption maxima at $435 \mathrm{~nm}$ and $668 \mathrm{~nm}$ [26], the blue and red regions, respectively. This is aimed at widening the absorption spectrum to capture the visible spectrum effectively to increase the efficiency of the device. The use of natural photosensitizers significantly reduces cost further and simplifies device fabrication.

For ensuring optimal device performance, the band gap of the pigments and the alignment of energy levels were verified using density functional theory (DFT) simulations using Gaussian09 [27]. DFT simulations of the pigment molecules are performed to identify the location of the highest occupied molecular orbital (HOMO) and lowest unoccupied molecular orbital (LUMO) levels, band gap and to understand the electron densities across the donor-linkeracceptor groups on the molecules. The dipole moment of the molecules and charge distribution could also be obtained from the DFT simulations which explain the reason for the strong binding of the pigment with the $\mathrm{TiO}_{2}$.

For solar cell applications, the lifetime of the device is also important. One of the important factors contributing to the lifetime of DSSCs is the stability of the pigments. Earlier studies show that co-adsorbents such as decyl-phosphonic acid (DPA) and hexa-decyl-malonic acid (HDMA) have been successfully used along with the dye in DSSCs form a hydrophobic layer and prevent the interaction of the $\mathrm{TiO}_{2}$ with the electrolyte [28]. Here, the long alkyl chains in these molecules self-assemble on the $\mathrm{TiO}_{2}$ surface to form a hydrophobic monolayer. Hence, it can be hypothesized that the chlorophyll that is being used in combination with betanin would not only increase the spectrum of absorption, the long hydrophobic alkyl chains of chlorophyll would also repel $\mathrm{I}^{-}$ions from interacting with $\mathrm{TiO}_{2}$ and reduce the recombination rate. Further, it would also 
prevent degradation of betanin, which is a more polar molecule and susceptible to degradation (electrolyte induced or light-induced) and help retain its efficiency for longer periods. Moreover, some studies in the field of textile dyeing indicate that chlorophyll used in combination with betanin as a mordant, helping in longer retention of the crimson color of betanin, protecting it from light-induced degradation [29].

Prior studies have been done where the performances of betanin and chlorophyll were compared which each other resulting in efficiencies of $0.04 \%$ and $0.02 \%$, respectively, for each [30]. Co-sensitization of betanin and chlorophyll has previously been tested that resulted in a combined efficiency of $0.294 \%$ [31].

In this paper, we report the performance of betanin-chlorophyll co-sensitized solar cell compared with the cells fabricated using the two aforementioned pigments individually, resulting in an average combined efficiency of $0.601 \%$, approximately twice of what has been previously achieved. Electrochemical impedance spectroscopy (EIS) studies have also been performed to assess the performance of the solar cells and co-relate it with their internal resistances and electron lifetimes. A brief study on the effect of light-induced degradation on these natural dye solar cells has also been elucidated.

\section{Methods}

\section{Computational studies on the natural pigments using Gaussian09}

Energy optimization of the dye molecules was done in Gaussian09 software using DFT hybrid functional Becke3-Lee-Yang-Parr (B3LYP) with 6-31G $(d, p)$ basis set [27]. The locations of the HOMO and the LUMO of the dye molecules were obtained with respect to vacuum energy level, and the band gap was calculated from the difference between these two energy levels. The location of electron densities on the molecules corresponding to the LUMO and HOMO energy levels were identified. The dipole moment of the molecule and its charge distribution could also be obtained from the simulations which explain the dipole-dipole interactions between the pigment molecule and $\mathrm{TiO}_{2}$.

\section{Preparation of the solar cell}

Regular fluorine-doped tin oxide (FTO) substrates (Solaronix) of dimensions, $15 \mathrm{~mm} \times 15 \mathrm{~mm} \times 1.1 \mathrm{~mm}$; resistivity $<10 \Omega / \mathrm{cm}$ and transmittance $>83 \%$ were thoroughly cleaned by sequentially ultra-sonicating for $15 \mathrm{~min}$ each, in deionized water, and detergent solution followed by ethanol [32]. $\mathrm{TiO}_{2}$ screen printing paste was prepared according to method optimized by Ito et al. [33]. The preparatory work was performed in ambient air at room temperature. To prepare the photo-electrode, the conducting side of the FTO glass was identified and the homogeneous $\mathrm{TiO}_{2}$ paste was coated onto the FTO substrate by the doctor-blading technique. The $\mathrm{TiO}_{2}$ electrodes were annealed at $450{ }^{\circ} \mathrm{C}$ for $1 \mathrm{~h}$ to eliminate any organics present [32]. $\mathrm{TiCl}_{4}$ treatment of the photoelectrode was done according to previously optimized methods $[17,33]$. The $\mathrm{TiCl}_{4}$ treatment is a necessary part of the photo-electrode preparation and is a key step that ensures better performance of the device. The mechanism of this enhancement can be described by the formation of $\mathrm{TiO}_{2}$ nanoparticles due to the hydrolyzation of the $\mathrm{TiCl}_{4}$ solution. These crystallize upon annealing and enable better contact interface facilitating easier electron movement across the film. Due to this, the defect sites are reduced decreasing the recombination rate of the electrons, thereby enhancing their collection [34, 35]. The thickness of the $\mathrm{TiO}_{2}$ coating was verified using Carl Zeiss SteREO Discovery V20 optical microscope. For taking the extended image, we used the Z-stack option which takes the top surface and the bottom surface and then scans the whole depth of the layer to get the image. The thickness of the $\mathrm{TiO}_{2}$ layer was found to be approximately $22 \mu \mathrm{m}$.

Betanin and chlorophyll pigments were extracted and purified using methods described in the literature and used for the experiments $[17,31]$. Betanin was extracted from Beta vulgaris slices (red beetroot) using acidified $(0.1 \mathrm{~N}$ $\mathrm{HCl}$ ) ethanol and chlorophyll- $a$ was extracted from Spinacia oleracea (spinach). The resulting extracts were filtered to remove debris and stored under refrigerated dark conditions.

The photo-electrodes were immersed in each of the pigment extracts sequentially (betanin followed by chlorophyll-this sequence was found to last comparatively longer) and left to stand for $24 \mathrm{~h}$ in the dark. It was then rinsed gently with ethanol to remove debris and moisture and dried. Sensitization of the $\mathrm{TiO}_{2}$ electrode was confirmed visually. Platinum coated FTO plates (Solaronix) were used as the counter electrodes. The cell was assembled by sandwiching the $\mathrm{TiO}_{2}-\mathrm{FTO}$ photo-anode and the Pt-FTO counter electrode and filling the electrolyte in between the two electrodes. A gel electrolyte was used for the experiments and it was prepared using NMP ( $N$-methyl-2-pyrrolidone) solvent containing 6\% PVDF (polyvinylidene fluoride) polymer by weight. LiI/ $\mathrm{I}_{2}(1.0 \mathrm{M} / 0.1 \mathrm{M})$ was used as the iodine oxidation/reduction material in the gel electrolyte [36].

Solar cells of three configurations were fabricated: betanin solar cell, chlorophyll solar cell, and betanin-chlorophyll solar cell. The back side of the counter electrode was covered by a piece of copper sheet to prevent transmission losses. An active area of $0.25 \mathrm{~cm}^{2}$ was defined for all the experiments. A mask was used to define the active area. 


\section{Characterization and measurements}

The absorption spectra of betanin, chlorophyll- $a$ and betanin-chlorophyll mixture, were characterized using Shimadzu UV-2400 PC Series spectrophotometer across a wavelength range of 200-800 nm with a sampling interval of $0.5 \mathrm{~nm}$. The slit width of the instrument was set at $5 \mathrm{~nm}$.

The EIS of the solar cells was measured over a frequency range of $100 \mathrm{kHz}-10 \mathrm{mHz}$ at ambient conditions by a Biologic electrochemical workstation, with a constant DC voltage bias of $0.5 \mathrm{~V}$ (close to the open circuit voltage of the DSSC). Several research groups have already demonstrated a systematic approach to characterize EIS of DSSCs [37-40].

The EIS spectrum was then analyzed using ZSimpWin 3.1 software [41], using a suitable equivalent circuit model to obtain the parameters-electron-recombination resistance, electron-transport resistance and chemical capacitance in the solar cells.

The $I-V$ characteristics of the solar cells were measured using the Oriel ${ }^{\circledR}$ AAA class solar simulator that can replicate the entire solar spectrum. The solar cells were tested under 1-sun illumination (AM1.5G standard test conditions at $100 \mathrm{~mW} / \mathrm{cm}^{2}$ ). The performance characteristics of betanin solar cell, chlorophyll solar cell, and betanin-chlorophyll co-sensitized solar cells were measured. Samples of each configuration were prepared in triplicates and the measurements were taken multiple times to check repeatability and the stability of the solar cells.

\section{Results}

\section{Structure of the co-sensitized green solar cell}

The schematic structure of the natural pigment co-sensitized solar cell is shown in Fig. 1. FTO conductive glass substrate is coated with a $\mathrm{TiO}_{2}$ mesoporous film. The $\mathrm{TiO}_{2}$ film is cosensitized with betanin and chlorophyll, natural pigments which were extracted from beetroot and spinach, respectively. The pigment sensitized $\mathrm{TiO}_{2}$ coated FTO glass plate works as the photoanode. Platinum coated FTO glass plate was used as the catalytic counter electrode i.e. the cathode. Iodide/triiodide redox electrolyte is filled between the two electrodes.

The chemical structures of betanin and chlorophyll- $a$ are shown as an inset in Fig. 1. Betanin is a glycoside of betacyanin, having an indole-2-carboxylic acid moiety (betaine), which is $\mathrm{N}$-linked to a pyridine dicarboxylic acid group (betalamic acid) through an acetyl group. The conjugated bonds in these ring systems are responsible for absorbing visible light in the green region. As seen from its structure, betanin has several carboxylic acid groups, promising good dipole interactions with $\mathrm{TiO}_{2}$ and strong anchoring, and

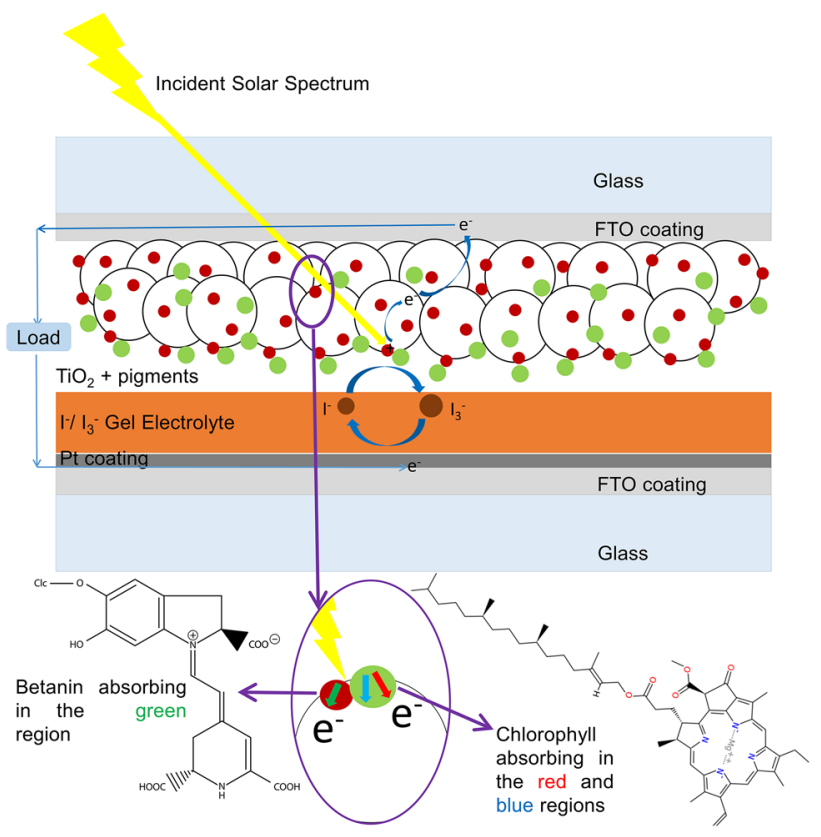

Fig. 1 Schematic representation of the device showing the complementary absorption by the co-sensitized pigments betanin and chlorophyll

hence is a good choice as a photo-sensitizer for solar cell applications.

Betanin binds to $\mathrm{TiO}_{2}$ by bi-dentate chelation [42] via the carboxyl groups. Chlorophyll- $a$ has a hydrophilic "head"the tetrapyrrole ring system which chelates a magnesium ion. A large cloud of electrons is present here due to alternating single and double bonds, which are responsible for the absorption of visible light in the red and blue regions. The long phytyl tail of chlorophyll- $a$ is hydrophobic and as a result, the molecule has an amphipathic nature. It is hypothesized that, in addition to complementing the absorption spectrum with betanin, the hydrophobic nature of the phytyl tail of chlorophyll- $a$ would also act as a protective layer preventing electrolyte induced degradation of the more polar betanin. The betanin and chlorophyll dyes used in this study were extracted from beetroot and spinach, respectively. No further modifications were carried out on the extracted dyes. For efficient conversion of sunlight to electricity, the combination of pigments used should have an absorption spectrum that closely matches the incident solar spectrum (300-1000 $\mathrm{nm}$ range) [43]. This was verified by UV-Vis absorption studies, described in the next section.

\section{Absorption studies of the pigments}

UV-Vis absorption studies were performed using Shimadzu UV-2400 PC Series spectrophotometer across a wavelength range of $200-800 \mathrm{~nm}$ with a sampling interval of $0.5 \mathrm{~nm}$. The slit width of the instrument was set at $5 \mathrm{~nm}$. 
Chlorophyll- $a$ was extracted from spinach using ethanol. To characterize the pigment extract, its absorption spectrum was measured (ethanol was used as the reference).

Peak absorbance was obtained at $435 \mathrm{~nm}$ and $668 \mathrm{~nm}$ (Fig. 2a), characteristic of chlorophyll- $a$, confirmed by values found in the literature [19]. The energy requirements of plants are satisfied by absorbing light only from the blue and red parts of the spectrum and chlorophyll absorbs very less between 500 and $600 \mathrm{~nm}$, where a significant fraction of the incident solar radiation falls. To maximize the efficiency of the solar cell, it is essential to broaden the absorption spectrum of the pigment used. Hence, to capture most of the incident solar radiation, a pigment absorbing in the green wavelength range is to be used which can effectively complement the absorption spectrum of chlorophyll. Betalains and anthocyanins are the two main classes of natural pigments absorbing strongly in the green region of the incident solar spectrum. However, by studying the structures of these pigments, it was concluded that anthocyanins were less stable and more prone to oxidation as compared to betanins and, moreover, betanin has stronger anchoring groups to $\mathrm{TiO}_{2}$, and hence was chosen as the complementary pigment to chlorophyll. Betanin was extracted from beetroot and characterized by measuring the absorption spectrum (ethanol was used as reference). Peak absorbance of the extract was observed at $535 \mathrm{~nm}$, which is the characteristic of betanin [15] (Fig. 2b). Next, both the pigments were mixed in a 1:1 ratio and the absorption spectrum of the mixture of betanin and chlorophyll was also characterized. As expected, the peaks around $430 \mathrm{~nm}$ and $670 \mathrm{~nm}$ match with those of chlorophyll and the peak at $535 \mathrm{~nm}$ matches with that of betanin (Fig. 2c).

Comparison of the spectra shows that the combined absorption spectrum overlaps better with the spectrum of the incident solar radiation (300-1000 $\mathrm{nm}$ range) [43]. Absorption of light by the pigments leads to the generation of photo-carriers, however, for effective charge transfer, it necessary to verify that the LUMO and HOMO energy levels of the pigment molecules align appropriately with those of $\mathrm{TiO}_{2}$ and the electrolyte, respectively.

\section{Density functional theory (DFT) studies of betanin and chlorophyll-a}

A good overlap of the energy levels between the LUMO of the dye molecule and the conduction band of titanium dioxide is necessary for fast electron transfer into the conduction band of the $\mathrm{TiO}_{2}$ [42]. DFT simulations using Gaussian09 were performed to verify the band gap of betanin and the alignment of its HOMO and LUMO energy levels.

Energy optimization of the betanin molecule was done using B3LYP, 6-31G $(d, p)$ basis set. The convergence criterion was set to $10^{-6}$ Hartrees. Energy optimization helped in the optimization of the betanin molecule into an energyfavorable conformation. DFT simulations yielded key results such as the energy levels of molecular orbitals (with respect to vacuum), electron density distribution of the molecular orbitals, charge distribution on the molecule and its dipole moment. The HOMO and LUMO energy levels were identified and the band gap was calculated based on the difference between the values of these two levels. Bandgap calculated from the predicted HOMO and LUMO levels was found to be $2.1 \mathrm{eV}$. This value is close to $2.31 \mathrm{eV}$, calculated from the absorption peak of betanin at $535 \mathrm{~nm}$, reported in the literature [15]. UV-Vis absorption maxima of the extracted betanin was also experimentally verified to be at $535 \mathrm{~nm}$ (Fig. 2a). On photo-excitation, electron density shifts from HOMO level to the LUMO level of betanin. Molecular Orbital (MO) analysis revealed that the electron density corresponding to the HOMO levels is located around the betaine moiety of betanin (Fig. 3a).

The $\mathrm{N}$-atom of betaine has a pair of non-bonding electrons, which are involved in delocalization with the $\pi$ electrons of the ring systems. These form the lower energy state or the HOMO energy level. The anti-bonding $\pi^{*}$ orbitals correspond to the higher energy state or the LUMO level of betanin. Excitation of the non-bonding electrons to the antibonding $\pi^{*}$ orbital correspond to the $n \rightarrow \pi^{*}$ transitions. The $n \rightarrow \pi^{*}$ transitions are low-energy transitions that occur by absorption of a photon in the green wavelength range, thus responsible for the reddish colour of betanin. The energy required for this transition is the band gap of the pigment.
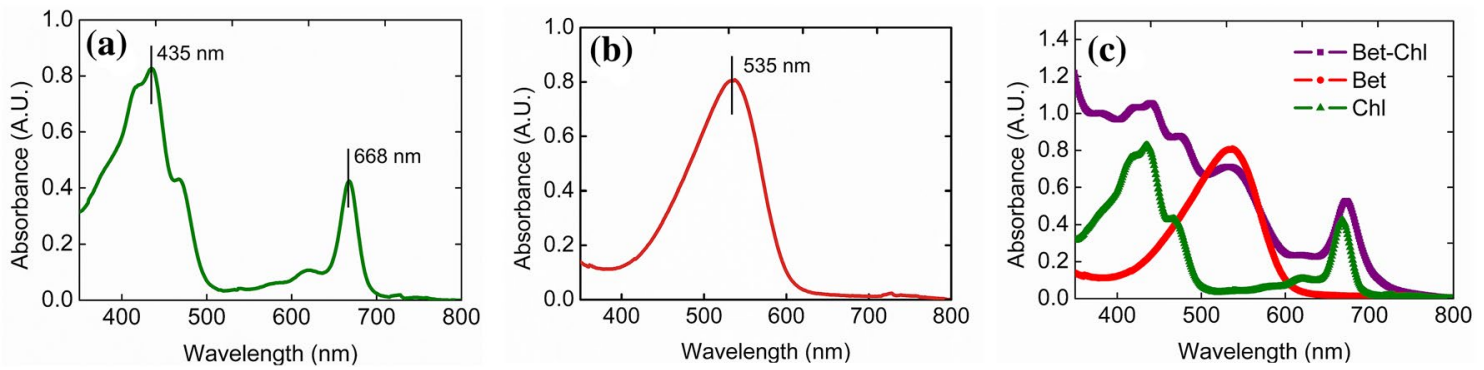

Fig. 2 Absorption spectrum of a chlorophyll- $a$, b betanin and $\mathbf{c}$ betanin-chlorophyll 1:1 mixture 


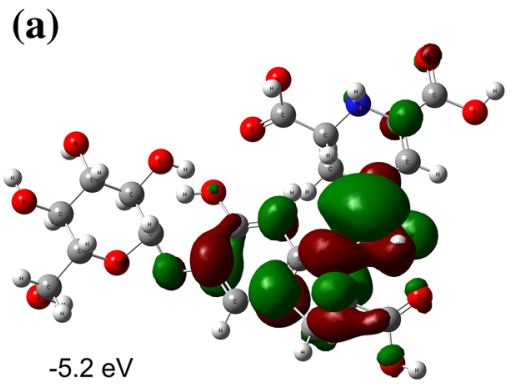

(d)

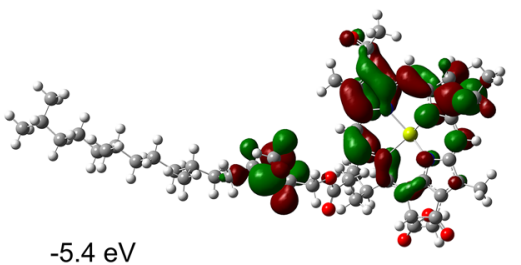

(b)

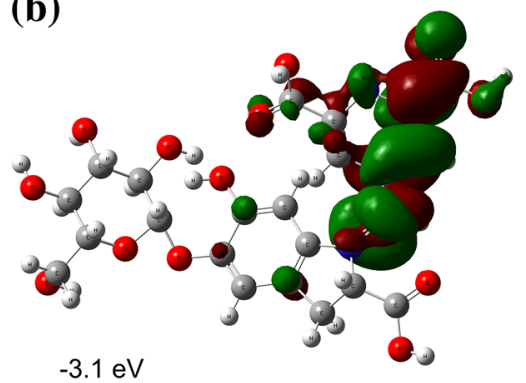

(e)

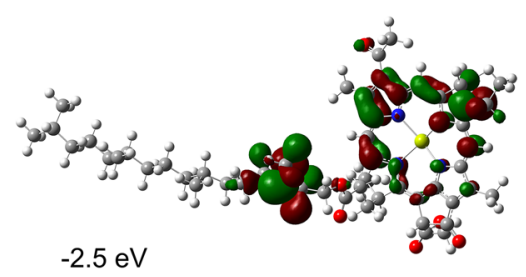

(c)

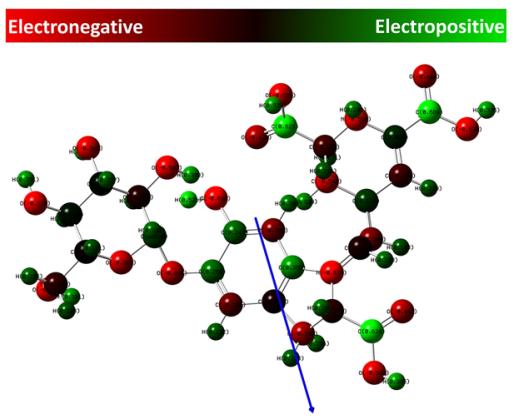

(f)

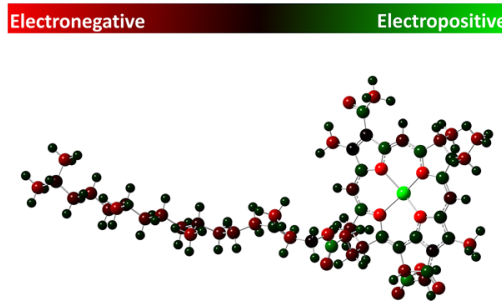

(g)

From DFT studies

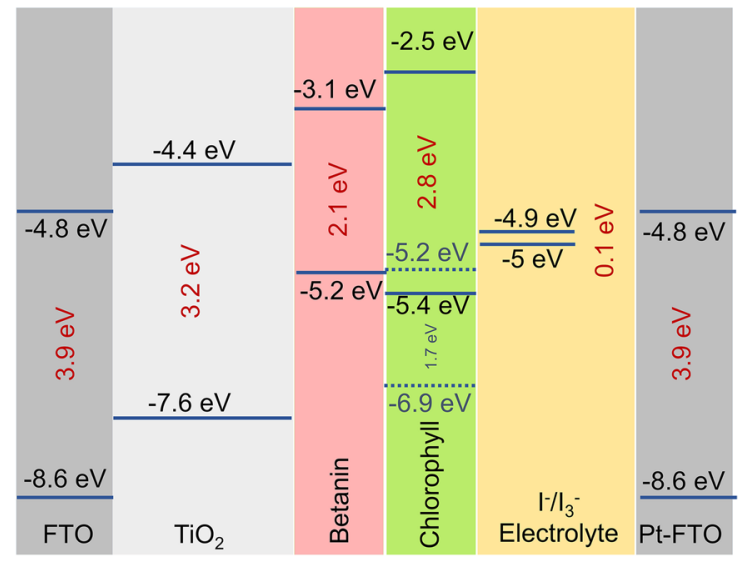

Fig. 3 Electron density corresponding to the a HOMO energy level of betanin $\mathbf{b}$ and the LUMO energy level of betanin. $\mathbf{c}$ The charge distribution on the betanin molecule. Electron density corresponding to the d HOMO energy level of chlorophyll e and the LUMO energy level of chlorophyll. $\mathbf{f}$ The charge distribution on the chlorophyll molecule. g Band diagram showing the alignment of energy levels (with respect to vacuum) of betanin and chlorophyll relative to the other components of the solar cell

(as seen in Fig. 3e) show strong electron withdrawing nature. Oxygen is an electronegative atom and when bound to this electropositive carbonyl carbon and hydrogen, a strong permanent dipole is created. Gaussian09 simulation of the charge distribution on betanin shows a net dipole moment of 8.69 Debye from the betalamic acid moiety to the betaine moiety. The strong dipole-dipole interaction between the pigment and $\mathrm{TiO}_{2}$ enables good anchoring required for better electron injection into the conduction band. The highly electropositive carbonyl carbons of carboxylic acid groups 
electropositive carbonyl carbon of carboxylic acid groups of betalamic acid draws electrons from the pyridine ring of betalamic acid which is subsequently injected into the conduction band of $\mathrm{TiO}_{2}$.

The basis sets available in Gaussian09 are unable to accurately calculate the energy levels of the chlorophyll molecule, however, this molecule has been widely studied in the literature [44, 45]. A study by Gonzalez et al. [44], indicates that only M06L density functional are able to produce sufficiently accurate results for the chlorophyll- $a$ molecule. Studies indicate that the HOMO-LUMO transitions occur in the hydrophilic $\mathrm{Mg}$ co-ordinated tetrapyrrole ring of chlorophyll, which is the region that binds to $\mathrm{TiO}_{2}$ [44]. The first set of HOMO and LUMO orbitals gave a band gap of $1.69 \mathrm{eV}$, corresponding to absorption at a wavelength of $668 \mathrm{~nm}$. The second set of HOMO and LUMO orbitals gave a band gap of $2.75 \mathrm{eV}$ (only this set of HOMO and LUMO levels of chlorophyll, could be obtained by Gaussian09 and are shown in Fig. 3d, e), corresponding to the absorption at a wavelength of $435 \mathrm{~nm}$ [44]. The charge distribution on the chlorophyll molecule is shown in Fig. 3f. Magnesium ion at the center of the porphyrin ring is highly electropositive. The electronegative nitrogens of the tetra-pyrrole ring lose a hydrogen and co-ordinate with the magnesium ion. Chlorophyll- $a$ has a dipole moment between 5.57 and 7.58 Debye.

The difference between reduction and oxidation potentials of each material, with respect to normal hydrogen electrode (NHE) reference, is the band gap of the material. Using this, the energy levels of all the materials in the solar cell can be calculated with respect to vacuum [46]. With the HOMO and LUMO levels identified and the band gap values verified through Gaussian09 simulations, the alignment of the energy levels with respect to the other components of the DSSC can be predicted. For optimum performance of the solar cell, the LUMO level of the dyes must be above the conduction band of $\mathrm{TiO}_{2}$ and the HOMO level of the dyes must be below the redox potential of the electrolyte. The band diagram (Fig. 3g) shows that the energy levels of betanin are aligned appropriately. Of the two sets of HOMO and LUMO levels of chlorophyll, only one set of energy levels are aligned appropriately while the other set is not (Fig. 3g). This can result in recombination and negatively affect the performance of chlorophyll in the solar cell.

\section{Electrochemical impedance spectroscopic (EIS) studies of DSSCs}

Electrical impedance spectroscopy is a diagnostic tool used for understanding the physical processes in DSSCs. Nyquist plots of DSSCs typically have two semicircles. The semicircle with the smaller real part corresponds to the electron transfer processes at the $\mathrm{Pt}$ counter electrode/electrolyte interface and in the $\mathrm{TiO}_{2}$ film. The semicircle with the larger real part corresponds to the electron recombination in the $\mathrm{TiO}_{2}$ film. Determination of physical parameters from EIS spectra of DSSCs is done by fitting the spectra to an equivalent circuit model that simulates the physical processes in the device. The modeling of the DSSC into an equivalent circuit model is shown in Fig. 4a [39].

The impedance $Z(f)$ of this model is given by Eq. (1):

$$
Z(f)=R_{\mathrm{s}}+\frac{R_{\mathrm{Pt}}}{R_{\mathrm{Pt}} Q_{\mathrm{Pt}}(j 2 \pi f)^{\alpha_{1}}+1}+\frac{R_{\mathrm{TiO}_{2}}}{R_{\mathrm{TiO}_{2}} Q_{\mathrm{TiO}_{2}}(j 2 \pi f)^{\alpha_{2}}+1},
$$

where $R_{\mathrm{s}}$ is the series resistance in the transparent conducting glass (FTO) and the transport loss in the electrolyte layer, $R_{\mathrm{Pt}}$ is the resistance to the charge transfer between electrons at the Pt electrode and $\mathrm{I}_{3}{ }^{-}$ions of the electrolyte, $Q_{\mathrm{Pt}}$ is the capacitance at the Pt electrode/electrolyte interface, $R_{\mathrm{TiO}_{2}}$ is the impedance to recombination at the $\mathrm{TiO}_{2} /$ electrolyte interface and $Q_{\mathrm{TiO}_{2}}$ is the chemical capacitance of the $\mathrm{TiO}_{2}$ film permeated with electrolyte $[37,47]$.
Fig. 4 a Equivalent circuit model used for fitting Nyquist plots. Nyquist plots generated from equivalent circuit model fit with measured data for $\mathbf{b}$ chlorophyll, $\mathbf{c}$ betanin and $\mathbf{d}$ betanin-chlorophyll solar cells
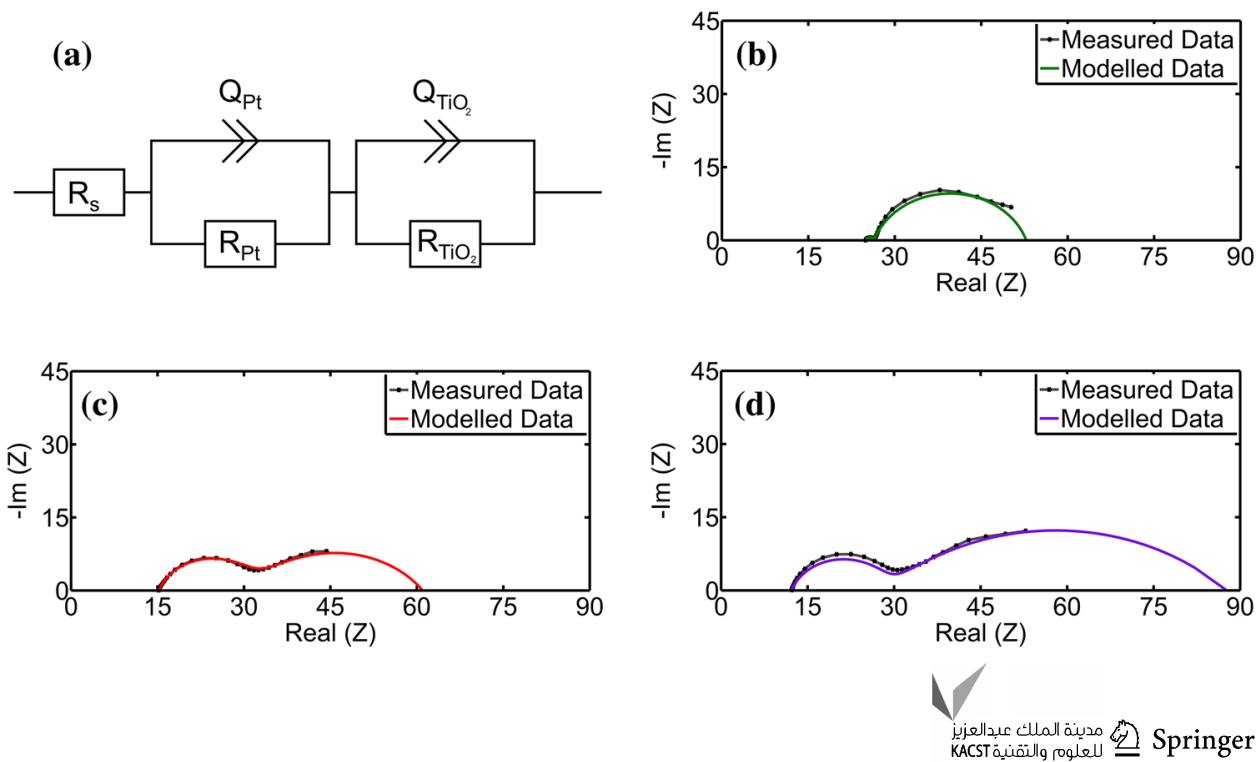
Constant phase element (CPE), represented as $Q$ describes imperfect capacitive processes which occur when the CPE index $\alpha$ departs from 1 . Pure capacitance with $\alpha=1$ is very rare in DSSCs, and the observed value is often lesser than 1. (CPE elements are used to represent the capacitive processes in such systems to accurately fit the data [47]).

The measured Nyquist plots of each configuration of the solar cell were fit into the equivalent circuit model (Fig. 4a) using ZSimpWin 3.1 software [41], and the relevant parameters are summarized in Table 1.

$\chi^{2}$ (Chi Square) value is minimized to determine the goodness-of-fit of the model. Values of orders less than $\sim 10^{-4}$ are considered as a good fit error of less than $1 \%$. Figure $4 b-d$ show the measured Nyquist plots fitted with the Nyquist plot generated by the above equivalent circuit model, having a good match with the observations.

In this study, the photo-anode (i.e. the electrode with the $\mathrm{TiO}_{2}-$ dye) is of primary interest. The internal resistance of the DSSCs and the mechanism of electron transport were investigated by the EIS to assess the performance of DSSCs and relate it to their internal resistances and electron lifetimes.

For a good solar cell, the impedance to recombination processes must be high. The charge transfer resistance at the photoanode-electrolyte interface is proportional to the lifetime of electrons $(\tau)$ at the photoanode. High charge transfer resistance and capacitance mean a longer electron lifetime and lesser probability of recombination at the electrode-electrolyte interface [48]. The recombination of electrons from the $\mathrm{TiO}_{2}$ conduction band to the redox electrolyte reduces the efficiency of the cell. Hence, a higher value of $\tau$ is favorable. Electron lifetimes of the three solar cell configurations were calculated using Eq. (2) [49] and are listed in Table 1:

$\tau=(Q * R)^{1 / \propto}$.

Higher value of $R_{\mathrm{TiO}_{2}}$ of the betanin-chlorophyll solar cell $(59.26 \Omega)$, compared to that of betanin solar cell $(29.68$
$\Omega)$ and chlorophyll solar cell $(25.56 \Omega)$, and higher value of $Q_{\mathrm{TiO}_{2}}$ of the betanin-chlorophyll solar cell at $0.009 \mathrm{~F} \mathrm{~s}^{\alpha-1}$ compared to that of betanin solar cell $\left(0.004 \mathrm{~F} \mathrm{~s}^{\alpha-1}\right)$ and chlorophyll solar cell $\left(0.002 \mathrm{~F} \mathrm{~s}^{\alpha-1}\right)$, can be attributed to the less charge recombination from dye- $\mathrm{TiO}_{2}$ photo-anode to the triiodide ions in the electrolyte in betanin-chlorophyll solar cell.

The calculated electron lifetime in the co-sensitized solar cell is higher ( $284.45 \mathrm{~ms}$ ) compared to $47.63 \mathrm{~ms}$ in the betanin solar cell and $25.29 \mathrm{~ms}$ in the chlorophyll solar cell. The higher lifetime implies lower recombination rate of electrons which will result in better short-circuit current. This should reflect in the higher power conversion efficiency of the solar cell.

\section{Power conversion efficiency of the natural pigment-sensitized solar cells}

Solar cells of three configurations were fabricated: betanin solar cell, chlorophyll- $a$ solar cell, and betanin-chlorophyll solar cell. The $J-V$ characteristics of the three configurations were studied using Oriel ${ }^{\circledR}$ AAA class solar simulator under a standard AM1.5G illumination condition of $100 \mathrm{~mW} / \mathrm{cm}^{2}$. The active area of the cells is $0.25 \mathrm{~cm}^{2}$. Power conversion efficiencies of the solar cells were measured in the presence of a mask defining the active area of $0.25 \mathrm{~cm}^{2}$. The average values of open-circuit voltage $\left(V_{\text {oc }}\right)$, short-circuit current density $\left(J_{\mathrm{sc}}\right)$, fill factor $(\mathrm{FF})$, and power conversion efficiency $(\eta)$ derived from the $J-V$ curves of three samples of each configuration, are listed in Table 2.

Figure 5a shows the $J-V$ curves of the chlorophyll solar cell under AM 1.5 G illumination conditions. The different lines in each of the graphs indicate separate cells tested in each configuration. The highlighted lines are the $J-V$ curves of the solar cells giving average efficiency in the three different configurations. With only chlorophyll as the sensitizer,
Table 1 Parameters determined from EIS spectra of the DSSCs

Table 2 Average performance characteristics of the three solar cells being studied

\begin{tabular}{|c|c|c|c|c|c|c|c|}
\hline \multirow[t]{2}{*}{ Cell } & \multicolumn{7}{|c|}{ Parameters } \\
\hline & $R_{\mathrm{s}}(\Omega)$ & $R_{\mathrm{TiO}_{2}}(\Omega)$ & $Q_{\mathrm{TiO}_{2}}\left(\mathrm{~F} \mathrm{~s}^{\alpha-1}\right)$ & $\alpha$ & $\%$ error & $\chi^{2}$ & $\tau(\mathrm{ms})$ \\
\hline Bet. & 15.23 & 29.68 & 0.004 & 0.7 & $<0.54$ & $2.94 \mathrm{e}^{-5}$ & 47.63 \\
\hline Chl. & 24.92 & 26.39 & 0.002 & 0.8 & $<0.61$ & $3.82 \mathrm{e}^{-5}$ & 25.29 \\
\hline Bet.-chl. & 12.18 & 59.26 & 0.009 & 0.5 & $<0.58$ & $3.36 \mathrm{e}^{-5}$ & 284.45 \\
\hline
\end{tabular}

Electron lifetime $(\tau)$ is calculated using Eq. (2) by plugging in $R_{\mathrm{TiO}_{2}}, Q_{\mathrm{TiO}_{2}}$ and $\alpha$ values, all of which are denoted in bold in the Table

\begin{tabular}{llllllr}
\hline Cell & \multicolumn{5}{l}{ Performance characteristics } & \\
\cline { 2 - 6 } & $V_{\mathrm{oc}}(\mathrm{V})$ & $J_{\mathrm{sc}}\left(\mathrm{mA} / \mathrm{cm}^{2}\right)$ & $V_{\max }(\mathrm{V})$ & $J_{\max }\left(\mathrm{mA} / \mathrm{cm}^{2}\right)$ & \multicolumn{1}{l}{$\begin{array}{l}\text { Fill factor } \\
(\mathrm{FF})(\%)\end{array}$} & Efficiency $(\eta)(\%)$ \\
\hline Bet. & 0.53 & 1.00 & & & 64.57 & $0.562 \pm 0.0202$ \\
Chl. & 0.53 & 0.11 & 0.44 & 0.93 & 72.18 & $0.0472 \pm 0.0007$ \\
Bet.-chl. & 0.53 & 1.25 & 0.43 & 0.09 & 68.01 & $0.601 \pm 0.0080$ \\
\hline
\end{tabular}


Fig. $5 J-V$ characteristics of a chlorophyll solar cell, $\mathbf{b}$ betanin solar cell, $\mathbf{c}$ betanin-chlorophyll solar cell and the $\mathbf{d} P-V$ characteristics of the three configurations
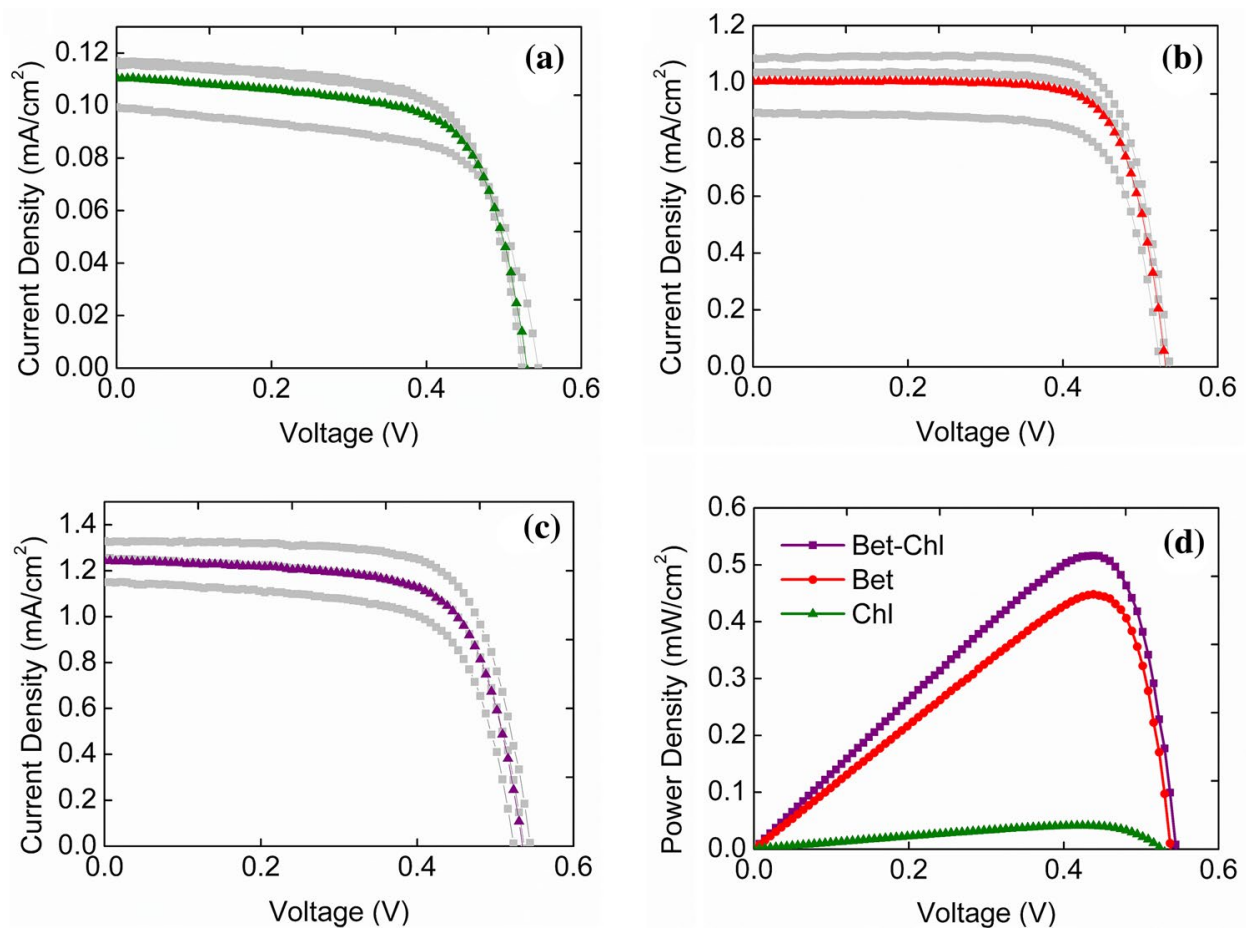

the solar cells show low performance, giving a maximum efficiency of $0.0483 \%$ with a $V_{\text {oc }}$ of $0.53 \mathrm{~V}, J_{\text {sc }}$ of $0.12 \mathrm{~mA} /$ $\mathrm{cm}^{2}$ and a fill factor of $72.18 \%$ (Fig. 5a). The chlorophyll cells had an average efficiency of $0.0472 \pm 0.0007 \%$. The betanin solar cells performed better than the chlorophyll solar cells with an average efficiency of $0.562 \pm 0.02 \%$. The betanin solar cell gave a maximum efficiency of $0.592 \%$ with a $V_{\mathrm{oc}}$ of $0.54 \mathrm{~V}, J_{\mathrm{sc}}$ of $1.08 \mathrm{~mA} / \mathrm{cm}^{2}$ and a fill factor of $64.57 \%$ (Fig. 5b). The better performance of betanin is due to better matching of the absorption peak of betanin with the incident solar spectrum. Betanin also has lesser steric hindrance while binding to $\mathrm{TiO}_{2}$ compared to chlorophyll, which is a bulkier molecule. Moreover, betanin has carboxylic acid groups that enable stronger binding with $\mathrm{TiO}_{2}$ enabling effective charge transfer. In addition, from the DFT studies (Fig. 3g), it was observed that the energy levels of betanin were more optimally aligned with respect the conduction band of $\mathrm{TiO}_{2}$ and the redox potential of the electrolyte. Whereas in the case of the chlorophyll molecule, only one set of energy levels were properly aligned, while the other set was not. This implies that the probability of recombination in chlorophyll sensitized solar cells is high. This was also observed in the EIS studies and is the reason for the lower efficiencies observed in chlorophyll solar cells.

When co-sensitized, the performance of the solar cell is better due to an increased current density which can be attributed to its increased absorption spectrum by the complementary absorbing regions of the two pigments. The cosensitized solar cell, had $V_{\mathrm{oc}}$ of $0.54 \mathrm{~V}$ and $J_{\mathrm{sc}}$ of $1.33 \mathrm{~mA} /$ $\mathrm{cm}^{2}$ with a fill factor of $71.42 \%$ and a maximum efficiency of $0.608 \%$ as seen in Fig. 5c. An average efficiency of $0.6 \pm 0.007 \%$ was achieved by the betanin-chlorophyll co-sensitized solar cell. An average increase in efficiency by $\sim 7 \%$ was observed, compared to a betanin solar cell. Figure $5 \mathrm{~d}$ clearly shows the betanin-chlorophyll co-sensitized solar cells has an increased power density compared to those fabricated using the pigments individually.

\section{Effect of photocatalytic activity of $\mathrm{TiO}_{2}$ on the lifetime of the solar cells}

A brief study on the lifetime of the DSSCs was performed to assess the effect of the photocatalytic activity (PCA) of $\mathrm{TiO}_{2}$ on the natural dyes sensitized onto it. On absorption of the high energy UV light in the solar spectrum, electrons in the valence band of $\mathrm{TiO}_{2}$ get excited to the conduction band. These high energy excited electrons on interaction with moisture, generate free radical ions (mainly reactive $\mathrm{OH}$ radicals) which are responsible for the photocatalytic activity of $\mathrm{TiO}_{2}$ and are capable of disintegrating organic matter in the vicinity [50]. This means that in the case of natural dye solar cells, which are not sealed by heat-based sealing techniques, moisture and oxygen can penetrate the device through the sides (between the photoanode and the counter electrode), rendering the natural pigments sensitized onto $\mathrm{TiO}_{2}$ prone to photocatalytic degradation.

Absorption studies were performed to study the degradation of the pigments betanin and chlorophyll due to the PCA of $\mathrm{TiO}_{2} . \mathrm{TiO}_{2}$ coated plates were immersed in betanin and chlorophyll pigments of the initial concentration of $5 \mathrm{mg} / \mathrm{l}$ and

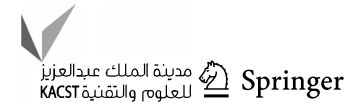


placed under the solar simulator (described previously) at a full light intensity ( 1 sun) and subjected to $5 \mathrm{~h}$ of constant light exposure. The absorption spectra of the pigments were studied at intervals of $1 \mathrm{~h}$ to observe the change in spectra due to the photocatalytic activity of $\mathrm{TiO}_{2}$ (seen in Fig. 6a, b).

Betanin and chlorophyll are compounds with a high presence of conjugated double bonds. In such molecules, the energy gap between the HOMO and LUMO is less which means that less energy is required for the electronic transitions. Therefore, these compounds absorb visible light $\left(\lambda_{\max }>400 \mathrm{~nm}\right)$ and appear colored. As these molecules are degraded, the degree of delocalization decreases. As the delocalization decreases, the energy of absorption required for electron transitions increases and, therefore, $\lambda_{\max }$ decreases [51]. This can be seen by the shift of the peaks towards the shorter wavelength region in both betanin and chlorophyll (blue-shift) in Fig. 6a, b. A decrease in the intensity of absorbance can be observed which implies a degradation of the dye molecules due to the PCA of $\mathrm{TiO}_{2}$. The dye color degradation can also be observed visually (as shown in Fig. 6c).

Pigment degradation has been found to follow first order kinetics [52]. The equation for first-order kinetics can be written as:

$\log \frac{C_{t}}{C_{0}}=-k t$

Here, $C_{t}$ is the concentration of the dye at time " $t$ ", $C_{0}$ is the initial concentration, $t$ is the irradiation time and $k$ is the rate constant [52]. The photocatalytic degradation kinetics of betanin and chlorophyll due to the $\mathrm{PCA}$ of $\mathrm{TiO}_{2}$ are shown in Fig. 6d. The adjusted $R^{2}$ value of the linear fit is found to be 0.9578 and the " $k$ " values of betanin and chlorophyll are 0.003 and 0.002 , respectively. About $90 \%$ degradation of betanin is observed within $4 \mathrm{~h}$, whereas in the case of chlorophyll, it takes $5 \mathrm{~h}$ for $90 \%$ degradation. From these studies, it can be inferred that degradation of chlorophyll is slower than betanin. The degradation of chlorophyll is slowed down by the presence of its bulky phytyl $C_{20}$ chain whereas the much smaller and more polar betanin molecule is more prone to degradation by the free radicals.

\section{Lifetime and stability of the solar cells}

The three solar cell configurations fabricated were also subjected to constant light exposure under the solar simulator (described previously), at an intensity of 1 sun for $5 \mathrm{~h}$. The efficiencies of the solar cells were measured at intervals of $30 \mathrm{~min}$ to observe the change in efficiency.

Figure 7a shows that the efficiency of the three configurations of solar cells decreases gradually with time. Although this decrease in efficiency can be attributed to $\mathrm{PCA}$ of $\mathrm{TiO}_{2}$ or degradation by the electrolyte, instability due to photocatalytic degradation seems to be one of the main reasons, as observed from the absorption spectra. As seen from the normalized plot (Fig. 7b), the decrease in efficiency of chlorophyll solar cells is $58.3 \%$ (0.048\% decreases to $0.02 \%$ in $5 \mathrm{~h}$ ) and is slightly less compared to the $64.9 \%$ decrease
Fig. 6 Photocatalytic activity of $\mathrm{TiO}_{2}$ resulting in a decrease in the intensity of absorbance by a betanin, $\mathbf{b}$ chlorophyll. $\mathbf{c}$ The degradation of dye color on the photoanodes over $5 \mathrm{~h}$. d Photocatalytic degradation follows first order kinetics
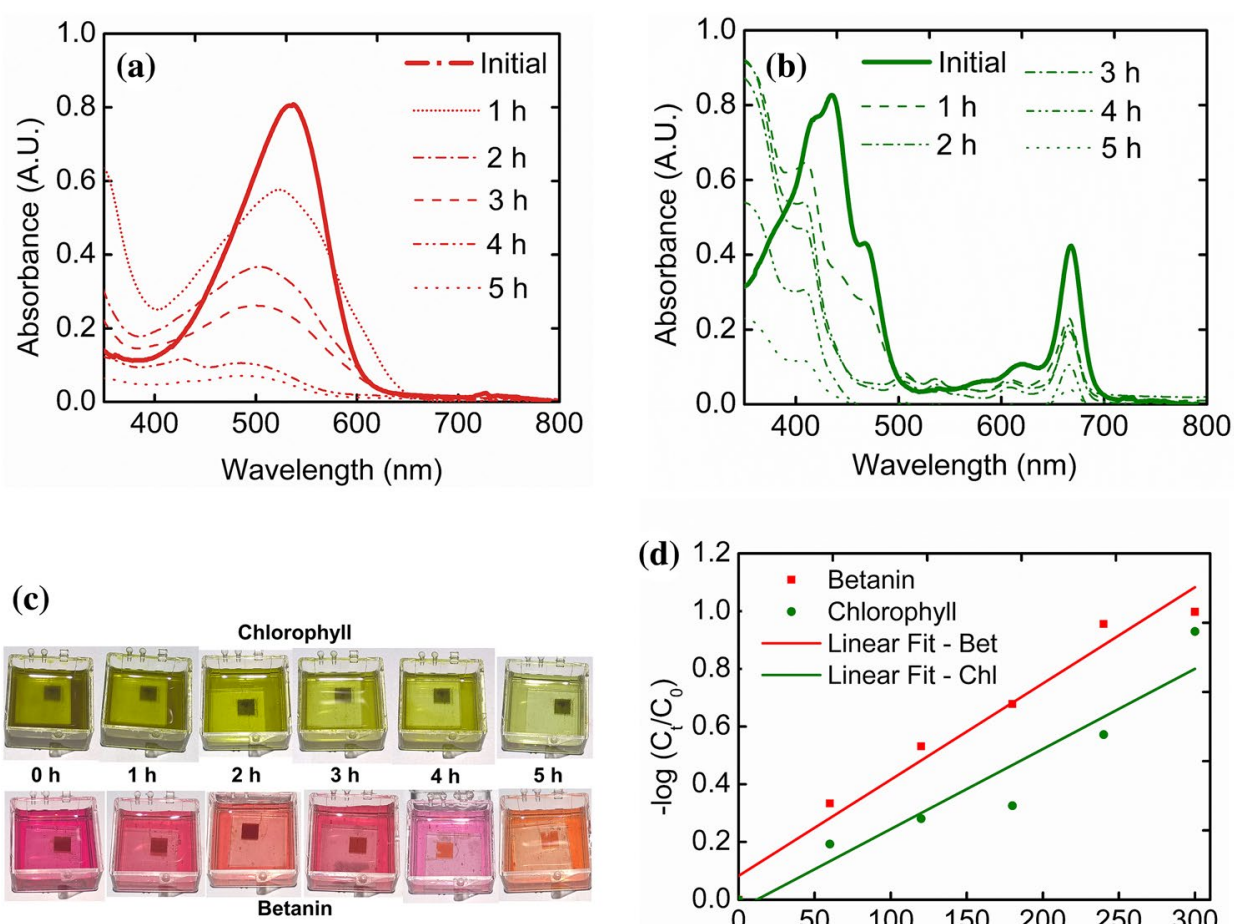
Fig. 7 Change in the efficiency of the three configurations of solar cells under $5 \mathrm{~h}$ of constant illumination: a absolute efficiency decrease. b Normalized efficiency decrease
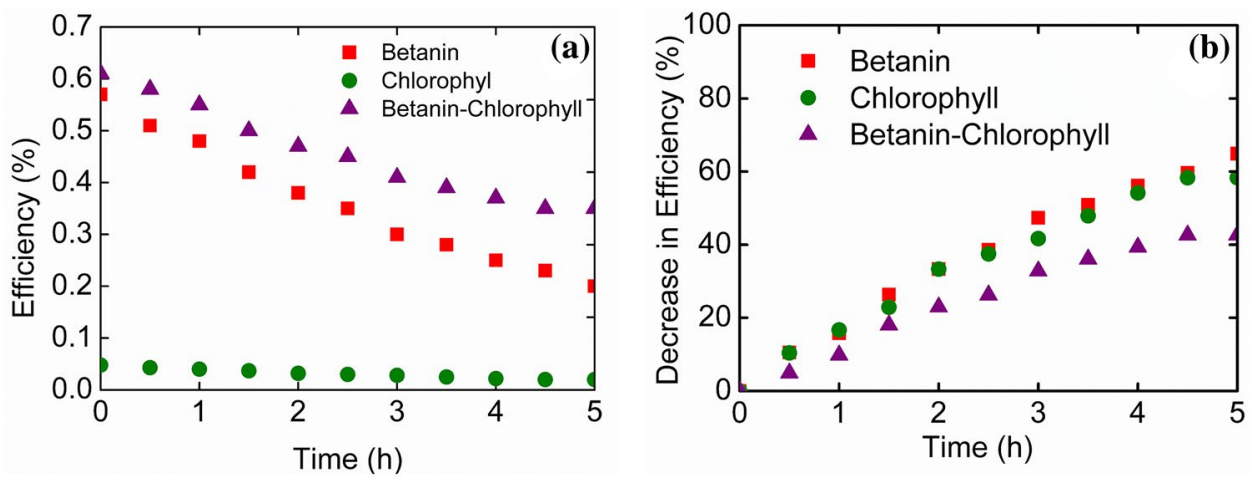

in efficiency of the betanin solar cells $(0.57 \%$ decreases to $0.2 \%$ in $5 \mathrm{~h}$ ). The co-sensitized solar cell has a comparatively better stability, with a $42.6 \%$ decrease in efficiency $(0.61 \%$ decreases to $0.35 \%$ in $5 \mathrm{~h}$ ).

Though the contribution of chlorophyll towards the combined efficiency was quite low compared to betanin, the presence of the hydrophobic phytl chains of chlorophyll act as a protective layer for betanin against degradation and aids in the better performance of the co-sensitized solar cell, enabling the enhancement of efficiency of the device by $0.1 \%$. The PCA studies showed that betanin is more prone to degradation than chlorophyll due to its small size and more polar nature compared to the chlorophyll with a bulky phytyl $\mathrm{C}_{20}$ chain. As mentioned earlier, some studies have indicated that chlorophyll when used with betanin, protects the latter from light-induced degradation [29]. Thus, cosensitization is able to take the advantage of better stability due to chlorophyll as well as better efficiency due to betanin. The presence of chlorophyll enables betanin to perform its best, while also contributing to increased light absorption.

In the natural pigment solar cells, the degradation of the pigment could also occur due to the contact with the electrolyte. Though chlorophyll solar cells show low efficiencies, it was noted that they did not decolorize as fast or as much as betanin solar cell did, possibly due to the lesser interaction of the pigment coated $\mathrm{TiO}_{2}$ with the iodide/triiodide electrolyte due to the hydrophobic nature of the tails. Betanin, being more polar in nature is more prone to degradation by interaction with the electrolyte. In the case of the co-sensitized solar cell, it was observed that both pigments lasted much longer due to a protecting hydrophobic nature of the phytyl tails of chlorophyll. It was also observed that the binding of betanin to $\mathrm{TiO}_{2}$ is enhanced in the presence of chlorophyll. Although the contribution of chlorophyll towards the efficiency of the betanin-chlorophyll co-sensitized solar cell is less, it appears that in the co-sensitized solar cell, the better performance of betanin as a sensitizer is complemented and stabilized by the presence of chlorophyll.

The stability and lifetimes of natural dye-based solar cells are generally low and require improvement. These studies indicate that the stability of natural dye-based DSSC is a major concern which requires careful engineering. The presence of oxygen, moisture, UV light and the presently used electrolytes affect the stability of the natural dyes. The photo-degradation of these natural dyes can be inhibited by the incorporation of compatible stabilizers and proper encapsulation methods. Techniques employed in conventional DSSCs can be readily adopted to improve the stability and lifetime of natural DSSCs.

Overall, the performances of the natural pigment based solar cells are still less compared to conventional ruthenium-based DSSC and further optimization is necessary to improve the performance of these solar cells. The present DSSC components are optimized for synthetic dyes. These components (such as the electrolyte and the photocatalytic $\mathrm{TiO}_{2}$ ) need to be replaced with materials that are more compatible with natural dyes to improve their stability. In summary, although natural dye-sensitized solar cells offer a low-cost option for entry into the commercial market of solar cells, there still remains large scope for further development of this technology to ensure their repeatability and reliability for the purpose of commercialization.

Although the efficiencies of natural dye solar cells are still quite far from the requirements for practical applications, the results are encouraging enough to orient future research towards the development of stacked configurations of multiple natural pigments in combination with nanoparticle additives to increase the efficiencies further.

\section{Conclusion}

In this work, we have reported an investigation on a combination of natural photosensitizers. The performances of the solar cells sensitized with individual pigments have been described and compared with respect to one another and also their co-sensitized performance. The broad absorption spectrum attributed to co-sensitization of betanin with chlorophyll resulted in higher efficiencies of the co-sensitized solar cells than using the pigments individually, due to increased

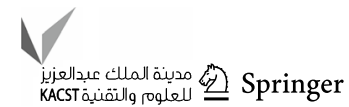


current density. The co-sensitized solar cell showed a higher efficiency of $0.601 \%$ compared to efficiencies of $0.562 \%$ and $0.047 \%$ obtained for betanin and chlorophyll solar cells, respectively. As confirmed by EIS, the better performance is due to the longer electron lifetime in the co-sensitized solar cell. The electron lifetime in the co-sensitized solar cell is much longer ( $284.45 \mathrm{~ms}$ ) compared to $25.29 \mathrm{~ms}$ in the chlorophyll solar cell and $47.63 \mathrm{~ms}$ in the betanin solar cell. The co-sensitization seems to improve the stability of the solar cell against light-induced degradation. Though the contribution of chlorophyll towards the combined efficiency was quite low compared to betanin, the presence of the hydrophobic phytl chains of chlorophyll acts as a protective layer for betanin against degradation and aids in the better performance of the co-sensitized solar cell, enabling the enhancement of efficiency of the device by $0.1 \%$.

Overall, the performances of the natural pigment based solar cells are still less compared to conventional ruthenium-based DSSC and further optimization is necessary to improve the performance of these solar cells. A lifetime of these cells can be enhanced/improved using stabilizers, sealing techniques, etc. as reported in the literature. Although the efficiencies of natural dye solar cells are still quite far from the requirements for practical applications, the results are encouraging enough to orient future research towards the development of stacked configurations of multiple natural pigments absorbing different wavelengths including nearinfrared wavelengths, development of green solar-battery hybrids and further optimization of the dye solar cell components compatible with such natural dyes.

Acknowledgements The authors would like to thank Dr. K. Ramesha, Principal Scientist, CSIR-CECRI and Dr. V. V. Giridhar, Former Scientist-in-Charge, CSIR-CECRI Madras unit for the kind support and facilities provided to carry out the work. We would like to thank Dr. Sathish Ogale, and his research group at CSIR-NCL for their valuable inputs. We would also like to thank our colleague Ms. Sumon Dey, who helped with the MATLAB modeling of Nyquist plots. The first author, S. Sreeja acknowledges the Council of Scientific and Industrial Research (CSIR), Government of India for the award of Senior Research Fellowship (Award no. 31/57(002)/2015-EMRI) to pursue research at CSIR-CEERI.

Open Access This article is distributed under the terms of the Creative Commons Attribution 4.0 International License (http://creativeco mmons.org/licenses/by/4.0/), which permits unrestricted use, distribution, and reproduction in any medium, provided you give appropriate credit to the original author(s) and the source, provide a link to the Creative Commons license, and indicate if changes were made.

\section{References}

1. Badawy, W.A.: A review on solar cells from Si-single crystals to porous materials and quantum dots. J. Adv. Res. 6, 123-132 (2015). https://doi.org/10.1016/j.jare.2013.10.001
2. Brédas, J.-L., Norton, J.E., Cornil, J., Coropceanu, V.: Molecular understanding of organic solar cells: the challenges. Acc. Chem. Res. 42, 1691-1699 (2009). https://doi.org/10.1021/ar900099h

3. Hardin, B.E., Snaith, H.J., McGehee, M.D.: The renaissance of dye-sensitized solar cells. Nat. Photonics 6, 162 (2012). https:// doi.org/10.1038/nphoton.2012.22

4. O'Regan, B., Grätzel, M.: A low-cost, high-efficiency solar cell based on dye-sensitized colloidal $\mathrm{TiO}_{2}$ films. Nature 353, 737-740 (1991). (ISSN 0028-0836)

5. Arora, N., Dar, M.I., Hinderhofer, A., Pellet, N., Schreiber, F., Zakeeruddin, S.M., Grätzel, M.: Perovskite solar cells with $\mathrm{CuSCN}$ hole extraction layers yield stabilized efficiencies greater than 20\%. Science 358, 768-771 (2017). https://doi.org/10.1126/ science.aam5655

6. Gratzel, M.: The advent of mesoscopic injection solar cells. Prog. Photovolt. Res. Appl. 14, 429-442 (2006). https://doi. org/10.1002/pip

7. Boschloo, G., Hagfeldt, A.: Characteristics of the iodide/triiodide redox mediator in dye-sensitized solar cells. Acc. Chem. Res. 42, 1819-1826 (2009). https://doi.org/10.1021/ar900138m

8. Kay, A., Graetzel, M.: Artificial photosynthesis. 1. Photosensitization of titania solar cells with chlorophyll derivatives and related natural porphyrins. J. Phys. Chem. 97, 6272-6277 (1993). https ://doi.org/10.1021/j100125a029

9. Nazeeruddin, M.K., Liska, P., Moser, J., Vlachopoulos, N., Grätzel, M.: Conversion of light into electricity with trinuclear ruthenium complexes adsorbed on textured $\mathrm{TiO}_{2}$ films. Helv. Chim. Acta 73, 1788-1803 (1990). https://doi.org/10.1002/hlca.19900 730624

10. Klein, C., Nazeeruddin, K., Censo, D.Di, Liska, P., Grtzel, M., Gra, M.: Amphiphilic ruthenium sensitizers and their applications in dye-sensitized solar cells. Inorg. Chem. 43, 4216-4226 (2004). https://doi.org/10.1021/ic049906m

11. Ma, X., Hua, J., Wu, W., Jin, Y., Meng, F., Zhan, W., Tian, H.: A high-efficiency cyanine dye for dye-sensitized solar cells. Tetrahedron 64, 345-350 (2008). https://doi.org/10.1016/j. tet.2007.10.094

12. Campbell, W.M., Jolley, K.W., Wagner, P., Wagner, K., Walsh, P.J., Gordon, K.C., Schmidt-Mende, L., Nazeeruddin, M.K., Wang, Q., Grätzel, M., Officer, D.L.: Highly efficient porphyrin sensitizers for dye-sensitized solar cells. J. Phys. Chem. C 111, 11760-11762 (2007). https://doi.org/10.1021/jp0750598

13. Wang, X.F., Kitao, O.: Natural chlorophyll-related porphyrins and chlorins for dye-sensitized solar cells. Molecules 17, 4484-4497 (2012). https://doi.org/10.3390/molecules 17044484

14. Richhariya, G., Kumar, A., Tekasakul, P., Gupta, B.: Natural dyes for dye sensitized solar cell: a review. Renew. Sustain. Energy Rev. 69, 705-718 (2017). https://doi.org/10.1016/j.rser.2016.11.198

15. Calogero, G., Bartolotta, A., Di Marco, G., Di Carlo, A., Bonaccorso, F.: Vegetable-based dye-sensitized solar cells. Chem. Soc. Rev. 44, 3244-3294 (2015). https://doi.org/10.1039/c4cs00309h

16. Ramamoorthy, R., Radha, N., Maheswari, G., Anandan, S., Manoharan, S., Victor Williams, R.: Betalain and anthocyanin dye-sensitized solar cells. J. Appl. Electrochem. 46, 929-941 (2016). https ://doi.org/10.1007/s10800-016-0974-9

17. Sandquist, C., McHale, J.L.: Improved efficiency of betanin-based dye-sensitized solar cells. J. Photochem. Photobiol. A Chem. 221, 90-97 (2011). https://doi.org/10.1016/j.jphotochem.2011.04.030

18. Al-Alwani, M.A.M., Ludin, N.A., Mohamad, A.B., Kadhum, A.A.H., Sopian, K.: Extraction, preparation and application of pigments from Cordyline fruticosa and Hylocereus polyrhizus as sensitizers for dye-sensitized solar cells. Spectrochim. Acta Part A Mol. Biomol. Spectrosc. 179, 23-31 (2017). https://doi. org/10.1016/j.saa.2017.02.026

19. Nan, H., Shen, H.P., Wang, G., Xie, S.D., Yang, G.J., Lin, H.: Studies on the optical and photoelectric properties of anthocyanin 
and chlorophyll as natural co-sensitizers in dye sensitized solar cell. Opt. Mater. 73, 172-178 (2017). https://doi.org/10.1016/j. optmat.2017.07.036

20. Chaiamornnugool, P., Tontapha, S., Phatchana, R., Ratchapolthavisin, N., Kanokmedhakul, S., Sang-aroon, W., Amornkitbamrung, V.: Performance and stability of low-cost dye-sensitized solar cell based crude and pre-concentrated anthocyanins: combined experimental and DFT/TDDFT study. J. Mol. Struct. 1127, 145-155 (2017). https://doi.org/10.1016/j.molstruc.2016.07.086

21. Talip, L.F.A., Ramli, M.M., Isa, S.S.M., Halin, D.S.C., Mazlan, N.S., Anhar, N.A.M., Danial, N.A., Muda, M.R.: Hybrid $\mathrm{TiO}_{2}$-gigantochloa albociliata charcoal in dye sensitized solar cell. IOP Conf. Ser. Mater. Sci. Eng. 209, 012086 (2017)

22. Orona-Navar, A., Aguilar-Hernández, I., Cerdán-Pasarán, A., López-Luke, T., Rodríguez-Delgado, M., Cárdenas-Chávez, D.L., Cepeda-Pérez, E., Ornelas-Soto, N.: Astaxanthin from Haematococcus pluvialis as a natural photosensitizer for dyesensitized solar cell. Algal Res. 26, 15-24 (2017). https://doi. org/10.1016/j.algal.2017.06.027

23. Kim, S.-H.: Functional Dyes. Elsevier, New York (2006)

24. Yamaguchi, M.: III-V compound multi-junction solar cells: present and future. Sol. Energy Mater. Sol. Cells 75, 261-269 (2003). https://doi.org/10.1016/S0927-0248(02)00168-X

25. Colonna, D., Capogna, V., Lembo, A., Brown, T.M., Reale, A., Di Carlo, A.: Efficient cosensitization strategy for dye-sensitized solar cells. Appl. Phys. Express 5, 22303 (2012). https:// doi.org/10.1143/APEX.5.022303

26. Zhou, H., Wu, L., Gao, Y., Ma, T.: Dye-sensitized solar cells using 20 natural dyes as sensitizers. J. Photochem. Photobiol. A Chem. 219, 188-194 (2011). https://doi.org/10.1016/j.jphot ochem.2011.02.008

27. Frisch, M.J., Trucks, G.W., Schlegel, H.B., Scuseria, G.E., Robb, M.A., Cheeseman, J.R., Scalmani, G., Barone, V., Mennucci, B., Petersson, G.A., Nakatsuji, H., Caricato, M., Li, X., Hratchian, H.P., IzmaylovAF, Bloino J., Zheng, G., Sonnenberg, J.L., Hada, M., Ehara, M., Toyota, K., Fukuda, R., Hasegawa, J., Ishida, M., Nakajima, T., Honda, Y., Kitao, O., Nakai, H., Vreven, T., Montgomery, J.A., Peralta, J.E., Ogliaro, F., Bearpark, M., Heyd, J.J., Brothers, E., Kudin, K.N., Staroverov, V.N., Kobayashi, R., Normand, J., Raghavachari, K., Rendell, A., Burant, J.C., Iyengar, S.S., Tomasi, J., Cossi, M., Rega, N., Millam, J.M., Klene, M., Knox, J.E., Cross, J.B., Bakken, V., Adamo, C., Jaramillo, J., Gomperts, R., Stratmann, R.E., Yazyev, O., Austin, A.J., Cammi, R., Pomelli, C., Ochterski, J.W., Martin, R.L., Morokuma, K., Zakrzewski, V.G., Voth, G.A., Salvador, P., Dannenberg, J.J., Dapprich, S., Daniels, A.D., Farkas Foresman, J.B., Ortiz, J.V., Cioslowski, J., Fox, D.J.: Gaussian 09 revision B.01. Gaussian, Inc., Wallingford, CT (2009)

28. Wang, P., Zakeeruddin, S.M., Comte, P., Charvet, R., HumphryBaker, R., Grätzel, M.: Enhance the performance of dye-sensitized solar cells by co-grafting amphiphilic sensitizer and hexadecylmalonic acid on $\mathrm{TiO}_{2}$ nanocrystals. J. Phys. Chem. B. 107, 1433614341 (2003). https://doi.org/10.1021/jp0365965

29. Guesmi, A., Ladhari, N., Ben, N., Msaddek, M., Sakli, F.: First application of chlorophyll- $a$ as biomordant: sonicator dyeing of wool with betanin dye. J. Clean. Prod. 39, 97-104 (2013). https:// doi.org/10.1016/j.jclepro.2012.08.029

30. Eli, D.: Chlorophyll and betalain as light-harvesting pigments for nanostructured $\mathrm{TiO}_{2}$ based dye-sensitized solar cells. J. Energy Nat. Resour. 5, 53 (2016). https://doi.org/10.11648/j.jenr.20160 505.11

31. Sengupta, D., Mondal, B., Mukherjee, K.: Visible light absorption and photo-sensitizing properties of spinach leaves and beetroot extracted natural dyes. Spectrochim. Acta Part A Mol.
Biomol. Spectrosc. 148, 85-92 (2015). https://doi.org/10.1016/j. saa.2015.03.120

32. Naphade, R.A., Tathavadekar, M., Jog, J.P., Ogale, S., Agarkar, S., Ogale, S.: Plasmonic light harvesting of dye sensitized solar cells by Au-nanoparticle loaded $\mathrm{TiO}_{2}$ nanofibers. J. Mater. Chem. A 2, 975-984 (2014). https://doi.org/10.1039/C3TA13246C

33. Ito, S., Chen, P., Comte, P., Nazeeruddin, M.K., Liska, P., Gra, M., Péchy, P., Grätzel, M.: Fabrication of screen-printing pastes from $\mathrm{TiO}_{2}$ powders for dye-sensitised solar cells. Prog. Photovolt. Res. Appl. 15, 603-612 (2007). https://doi.org/10.1002/pip.768

34. O'Regan, B.C., Durrant, J.R., Sommeling, P.M., Bakker, N.J.: Influence of the $\mathrm{TiCl}_{4}$ treatment on nanocrystalline $\mathrm{TiO}_{2}$ films in dye-sensitized solar cells. 2 . charge density, band edge shifts, and quantification of recombination losses at short circuit. J. Phys. Chem. C 111, 14001-14010 (2007). https://doi.org/10.1021/jp073 056p

35. Lee, S.W., Ahn, K.S., Zhu, K., Neale, N.R., Frank, A.J.: Effects of $\mathrm{TiCl}_{4}$ treatment of nanoporous $\mathrm{TiO}_{2}$ films on morphology, light harvesting, and charge-carrier dynamics in dye-sensitized solar cells. J. Phys. Chem. C 116, 21285-21290 (2012). https://doi. org/10.1021/jp3079887

36. Man-Gu, K., Park, N.-G., Kim, K.-M., Chang, S.-H.: Dye sensitized solar cells including polymer electrolyte gel containing poly(vinyldene fluoride). Patent No. US 6,756,537 B2 (2004)

37. Fabregat-Santiago, F., Bisquert, J., Garcia-Belmonte, G., Boschloo, G., Hagfeldt, A.: Influence of electrolyte in transport and recombination in dye-sensitized solar cells studied by impedance spectroscopy. Sol. Energy Mater. Sol. Cells 87, 117-131 (2005). https://doi.org/10.1016/j.solmat.2004.07.017

38. Fabregat-Santiago, F., Bisquert, J., Palomares, E., Otero, L., Kuang, D., Zakeeruddin, S.M., Grätzel, M.: Correlation between photovoltaic performance and impedance spectroscopy of dyesensitized solar cells based on ionic liquids. J. Phys. Chem. C 111, 6550-6560 (2007). https://doi.org/10.1021/jp066178a

39. Kern, R., Sastrawan, R., Ferber, J., Stangl, R., Luther, J.: Modeling and interpretation of electrical impedance spectra of dye solar cells operated under open-circuit conditions. Electrochim. Acta 47, 4213-4225 (2002). https://doi.org/10.1016/S0013 $-4686(02) 00444-9$

40. Zheng, D., Ye, M., Wen, X., Zhang, N., Lin, C.: Electrochemical methods for the characterization and interfacial study of dyesensitized solar cell. Sci. Bull. 60, 850-863 (2015). https://doi. org/10.1007/s11434-015-0769-0

41. Yemu, B.: Z SimpWin version:2; electrochemical impedance spectroscopy (EIS) data analysis software. Princeton Applied Research, Princeton, NJ (1999)

42. Park, K., Kim, T., Park, J., Jin, E., Yim, S., Choi, D., Lee, J.: Dyes and pigments adsorption characteristics of gardenia yellow as natural photosensitizer for dye-sensitized solar cells. Dye. Pigments 96, 595-601 (2013). https://doi.org/10.1016/j.dyepig.2012.10.005

43. (ASTM), A.S. for T. and M.: Reference solar spectral irradiance: air mass 1.5. Terrestrial reference spectra for photovoltaic performance evaluation (2003)

44. Alvarado-gonzález, M., Flores-holguín, N., Glossman-mitnik, D.: Computational nanochemistry study of the molecular structure and properties of chlorophyll $a$. Int. J. Photoenergy 2013, 8 (2013). https://doi.org/10.1155/2013/424620

45. Saito, K., Suzuki, T., Ishikita, H.: Absorption-energy calculations of chlorophyll $a$ and $b$ with an explicit solvent model. J. Photochem. Photobiol. A Chem. 358, 422-431 (2018). https://doi. org/10.1016/j.jphotochem.2017.10.003

46. Zoski, C.: Handbook of Electrochemistry. Elsevier Science, New York (2006)

47. Liberatore, M., Decker, F., Burtone, L., Zardetto, V., Brown, T.M., Reale, A., Di Carlo, A.: Using EIS for diagnosis of dye-sensitized

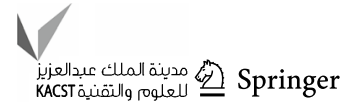


solar cells performance. J. Appl. Electrochem. 39, 2291-2295 (2009). https://doi.org/10.1007/s10800-009-9806-5

48. Sarker, S., Ahammad, A.J.S., Seo, H.W., Kim, D.M.: Review article: electrochemical impedance spectra of dye-sensitized solar cells: fundamentals and spreadsheet calculation. Int. J. Photoenergy 2014, 1-17 (2014). https://doi.org/10.1155/2014/851705

49. Wang, M., Chen, P., Humphry-baker, R., Zakeeruddin, S.M., Grätzel, M.: The influence of charge transport and recombination on the performance of dye-sensitized solar cells. Chem. Phys. Chem. 10, 290-299 (2008). https://doi.org/10.1002/cphc.200800708

50. Raja, V., Shiamala, L., Alamelu, K., Jaffar Ali, B.M.: A study on the free radical generation and photocatalytic yield in extended surfaces of visible light active $\mathrm{TiO}_{2}$ compounds. Sol. Energy Mater. Sol. Cells 152, 125-132 (2016). https://doi.org/10.1016/j. solmat.2016.03.008
51. Yan, Z., Gong, W., Chen, Y., Duan, D., Li, J., Wang, W., Wang, J.: Visible-light degradation of dyes and phenols over mesoporous titania prepared by using anthocyanin from red radish as template. Int. J. Photoenergy (2014). https://doi.org/10.1155/2014/968298

52. Hamad, H.A., Sadik, W.A., Abd El-Latif, M.M., Kashyout, A.B., Feteha, M.: Photocatalytic parameters and kinetic study for degradation of dichlorophenol-indophenol (DCPIP) dye using highly active mesoporous $\mathrm{TiO}_{2}$ nanoparticles. J. Environ. Sci. 43, 26-39 (2016). https://doi.org/10.1016/j.jes.2015.05.033

Publisher's Note Springer Nature remains neutral with regard to jurisdictional claims in published maps and institutional affiliations. 